\title{
PEMANFAATAN BUNGA ROSELLA (HIBISCUS SABDARIFFA L) PADA PEMBUATAN PUDDING BAVAROIS SUKEDBULA (SUSU KEDELAI BUNGA ROSELLA)
}

\author{
Isna Arista Gustiarani ${ }^{1}$ dan U. Yuyun Triastuti ${ }^{2}$ \\ Program Seni Kuliner Akademi Kesejahteraan Sosial Ibu Kartini Semarang, Indonesia \\ isnagusti@gmail.com dan yuyuntriastuti94@gmail.com
}

Received : 26-02-2021

Revised : 15-03- 2021

Accepted : 20-03- 2021

\section{Abstract}

Rosella (Hibiscus sabdariffa L) is a plant that has flowers with a characteristic sour taste and produces a red color, so it can be used as a flavoring and coloring agent in making bavarois pudding. The main ingredient in making bavarois pudding is cow's milk, but its use can be replaced with soy milk which is free of saturated fat. The use of rosella flowers as a pink dye and sour flavor, and soy milk to produce a healthy sukedbula bavarois pudding (rosella flower soy milk) that is safe for consumption. The main objective of this research is to develop Pudding bavarois made from soy milk, with flavor and roselle flower coloring, at 0\% (P0), 10\% (P1), 20\% (P2), and 30\% (P3). Thebavarois sukedbula pudding selected formula for theis with a percentage of rosella flower powder as much as $20 \%$ (P2) and the sukedbula bavarois pudding selectedcontains $24 \%$ vitamin C, $0.32 \%$ fat, and $4.35 \%$ protein. This study used an experimental method to obtain data by experimenting with making bavaroise sukedbula pudding, which is made from soy milk and rosella flower powder. The method of analyzing the collected data used qualitative and quantitative analysis, namely to determine the level of public preference, using descriptive analysis of the mean assessment, while laboratory tests were for chemical analysis. Savarois sukedbula pudding was selected after being tested, namely the treatment of $10 \%$ rosella powder, which was 11 grams which was used in making Pudding bavarois sukedbula. The sukedbula bavarois pudding contains levels of $24 \%$ vitamin $C, 0.32 \%$ fat, and $4.35 \%$ protein. Descriptively, the sensor assessment resulted in bavaroise sukedbula pudding with a bright pink color 3.8, sweet and sour taste that was fresh 3.6, dense texture soft foamy (foamy) 3.6, distinctive aroma of rosella 3.4, and overall preference favored by panelists 3.6.

Keywords : rosella flower; soy milk; bavarois pudding.

\footnotetext{
Abstrak

Rosella (Hibiscus sabdariffa L) merupakan tanaman yang memiliki bunga dengan ciri khas rasa asam, serta menghasilkan warna merah, sehingga dapat digunakan sebagai perasa dan pewarna pada pembuatan pudding
} 
bavarois. Bahan utama pada pembuatan pudding bavarois yaitu susu sapi, namun pemakaiannya dapat diganti menggunakan susu kedelai yang bebas lemak jenuh. Pemanfaatan bunga rosella sebagai pewarna merah muda dan perasa asam, serta susu kedelai untuk menghasilkan pudding bavarois sukedbula (susu kedelai bunga rosella) yang sehat sehingga aman untuk konsumsi. Tujuan utama penelitian ini yaitu mengembangkan Pudding bavarois berbahan susu kedelai, dengan perasa dan pewarna bunga rosella, sebesar $0 \%(\mathrm{P} 0), 10 \%(\mathrm{P} 1), 20 \%(\mathrm{P} 2)$, dan $30 \%$ (P3). Pudding bavarois sukedbula formula terpilih yaitu dengan persentase bubuk bunga rosella sebanyak $20 \%$ (P2) dan pudding bavarois sukedbula terpilih mengandung $24 \%$ vitamin C, $0.32 \%$ lemak, dan $4.35 \%$ protein. Penelitian ini menggunakan metode eksperimen untuk memperoleh data dengan melakukan percobaan pembuatan pudding bavaroise sukedbula, yang dibuat dari susu kedelai dan bubuk bunga rosella. Metode analisis data yang telah terkumpul, menggunakan analisis kualitatif dan kuantitatif yaitu untuk mengetahui tingkat kesukaan masyarakat, menggunakan analisis deskriptif penilalaian rerata, sedangkan uji laboratorium untuk analisis secara kimiawi. Pudding bavarois sukedbula perlakuan terpilih setelah diuji yaitu pada perlakuan pemanfaatn bubuk rosella sebanyak $10 \%$ yaitu 11 gram yang dimanfaatkan pada pembuatan Pudding bavarois sukedbula. Pudding bavarois sukedbula tersebut mengandung kadar $24 \%$ vitamin C, $0.32 \%$ fat, dan $4.35 \%$ protein. Secara deskriptif penilaian sensorinya menghasilkan pudding bavaroise sukedbula berwarna merah muda cerah 3.8 , berasa manis dan asam yang segar 3.6 , bertekstur padat berbusa lembut (foamy) 3.6, beraroma khas bunga rosela 3.4, serta kesukaan keseluruhan disukai panelis 3.6.

Kata kunci: bunga rosella; susu kedelai; pudding bavarois.

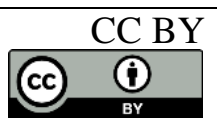

\section{PENDAHULUAN}

Rosella merupakan tanaman yang banyak tumbuh di daerah tropis seperti di Indonesia. Rosella merupakan tumbuhan perdu atau semak yang merupakan tanaman musiman. Tanaman rosella tumbuh dari biji atau benih serta berbunga hampir sepanjang tahun, bagian rosella yang bisa diproses menjadi makanan adalah kelopak bunganya yang mempunyai rasa amat masam (Haidar, Z, 2016).

Rosella (Hibiscus sabdariffa) merupakan salah satu tanaman yang dikenal memiliki manfaat fungsional bagi kesehatan. Bagian kelopak bunganya kaya akan antioksidan yang berperan sebagai pengikat radikal bebas dan sering dimanfaatkan sebagai pewarna alami (Handarini, 2014).

Kelopak bunga rosella adalah bagian tanaman yang bisa diproses menjadi produk pangan. Kelopak bunga tanaman ini berwarna merah tua, tebal, dan berair. Ekstrak 
kelopak bunga rosella mengandung vitamin $\mathrm{C}$ dalam jumlah yang tinggi setra asam suksinat dan asam oksalat yang merupakan dua asam organik yang dominan. Ekstrak kelopak bunga rosella juga mengandung asam askorbat yang lebih tinggi dari jeruk dan mangga (Suwandi, 2012).

Komponen senyawa kimia ekstrak bunga rosella pada produk kacang goyang yang berfungsi sebagai pewarna makanan juga mempunyai khasiat sebagai obat adalah Xhantosine, 5,5',7,7'- Tetrabromoindigo, Oleic acid, kimia linoleic acid, gammatecopherol, Vitamin E atau alphatecopherol, Squalene (Fauziati., 2016). Berdasarkan penelitian-penelitian yang terdahulu tentang pemanfaatan bunga rosella, sebagai pewarna alami dan pemberi rasa asam pada makanan, maka peneliti mengembangkan bunga rosella pada pembuatan pudding sukedbulla.

Pudding adalah sejenis makanan terbuat dari pati, yang diolah dengan cara merebus, kukus, dan membakar (boiled, steamed, and baked), pudding berasal dari adonan cair maupun setengah padat, yang dimasak kemudian dicetak dan dibekukan dalam cetakan dengan berbagai macam ukuran. Pudding dapat disajikan dalam berbagai kesempatan dengan berbagai variasi rasa, bentuk dan tekstur (Farida dkk, 2008).

Pudding merupakan salah satu bentuk dessert yang disajikan dalam suhu rendah. Banyak jenis pudding yang bisa dinikmati, salah satunya yaitu pudding busa atau yang dikenal dengan istilah bavarois, yang memiliki tekstur foamy, lembut seperti busa (Dwi, 2014). Pudding Pudding yang ditambah dengan putih telur yang dikocok hingga kaku akan menghasilkan pudding dengan tekstur yang lembut seperti busa yang dalam istilah asingnya disebut "Bavarois". Kesulitan yang sering membuat bavarois dikatakan gagal adalah adanya lapisan busa dan pudding jika telah membeku. Lapisan tersebut dapat saja terjadi jika pada saat pengadukan tidak homogen atau pada saat memasukkan adonan agar-agar dalam putih telur kocok sudah dalam suhu dingin (Ekawatiningsih, 2008).

Pudding busa disukai hampir oleh semua orang, baik orang dewasa maupun anak-anak. Pudding busa (bavarois) dapat disajikan dalam tampilan mewah sehingga sering disajikan saat acara spesial atau acara khusus (Ismayani, 2013)(Ismayani, 2007).

Penampilan pudding bavarois yang mewah, dalam pengolahannya dapat dikombinasikan dengan ekstrak bunga rosella. Kelebihan yang ada pada ekstrak bunga rosella, dapat menghasilkan warna merah dan rasa asam. Pemakaian ekstrak bunga pada pudding bavarois susu kedelai (pudding bavarois sukedbulla), diharapkan dapat menambah penampilan khususnya pada warna menjadi lebih menarik dan rasa yang segar.

Kesegaran yang dihasilkan dari ekstrak bunga rosella, karena kandungan vitamin $\mathrm{C}$ yang cukup tinggi. Kandungan gizi pada bunga rosella antara lain kalori $44 \mathrm{kkal}$, protein $1.6 \mathrm{~g}$, lemak $0.1 \mathrm{~g}$, karbohidrat $11.1 \mathrm{~g}$, dan serat $2.5 \mathrm{~g}$, abu $1.0 \mathrm{~g}$, kalsium $160 \mathrm{mg}$, fosfor $60 \mathrm{mg}$, betakaroten $285 \mathrm{ig}$, vitamin C $14 \mathrm{mg}$, tiamin $0.04 \mathrm{mg}$, ribovlavin $0.6 \mathrm{mg}$, serta $0.5 \mathrm{mg}$ (Maryani., 2008).

Manfaat kelopak bunga rosella dengan warna merah karena senyawa antosianin, yang dapat mengatasi kanker darah atau leukemia. Senyawa antosianin yang berperan sebagai antioksidan mampu meredam aksi radikal bebas yang menyerang molekul tubuh yang dapat menyebabkan oksidasi, kolesterol, lipid yang berujung pada penyakit kanker (Suryatmaja, 2008).

Penggunaaan bunga rosella merah lokal dalam pembuatan pudding bavarois susu kedelai bunga rosella yaitu dalam bentuk rosella bubuk. Merujuk dari hasil penelitian tentang pemanfaatan rosella dalam bentuk serbuk (Kusnadi, K \& K, 2020), maka proses pembuatan rosella bubuk yaitu:

1) Pengeringan, yaitu kelopak bunga rosella dikeringkan dengan suhu $60^{\circ}$ celcius, selama 15 menit. 
2) Penghalusan yaitu kelopak bunga rosella kering dihaluskan dengan menggunakan blender hingga halus.

3) Pengayakan yaitu kelopak bunga rosella yang telah halus kemudian diayak hingga didapatkan bubuk yang halus.

Penggunaan bunga rosella sebagai bahan pembuatan pudding bavarois ditujukan agar memberikan warna merah alami yang bagus, selain itu rasa asam pada bunga rosella juga akan memberikan rasa segar pada pudding. Selain bahan perasa dan pewarna yang digunakan dalam pembuatan pudding bavaroise, juga terdapat bahan cair. Bahan cair pada pudding bavaroise umumnya susu sapi. Susu sapi mempunyai ciri rasa yang gurih, dan protein yang tinggi, serta lemak. Namun lemak yang terkandung merupakan lemak jenuh, maka akan menyebabkan pudding bavaroise mengandung kolesterol jahat. Sebagai alternatif untuk mengurangi lemak jahat, maka susu sapi diganti dengan susu kedelai. Sedangkan susu kedelai dapat dimanfaatkan sebagai pengganti susu sapi dalam pembuatan pudding yaitu pada buku Pudding Susu Kedelai Tinggi Protein \& Rendah Kolesterol (Muaris, 2006). Susu kedelai juga merupakan produk lokal yang dalam pemanfaatannya masih kurang maksimal, hanya dikonsumsi langsung.

Berdasarkan Standar Nasional Indonesia (SNI), susu kedelai merupakan produk yang berasal dari ekstrak biji kacang kedelai. Susu kedelai nabati memiliki kandungan serat, asam lemak tak jenuh serta protein yang tinggi sehingga baik untuk kesehatan. Susu kedelai juga dapat menjadi alternatif pengganti susu sapi bagi orang yang alergi dan tidak menyukai susu sapi atau bagi mereka yang tidak dapat menjangkau harga susu sapi yang mahal karena susu kedelai harganya lebih murah jika dibandingkan dengan susu hewani, serta susu kedelai memiliki nilai gizi yang baik dan cocok untuk dikonsumsi untuk semua golongan usia (Picauly, P., 2018)..

Kandungan gizi pada susu kedelai menurut Deputi Menteri Negara Riset dan Teknologi Bidang Pendayagunaan dan Pemasyarakatan Ilmu pengetahuan dan teknologi (Pusat Informasi Wanita dalam Pembangunan, 2000), air $88.60 \%$, protein $4.40 \%$, lemak $2.50 \%$, karbohidrat 3.80\%, kalori $52.99 \%$, Vitamin B1 $0.04 \%$, Vitamin B2 $0.02 \%$, serta Vitamin A $0.02 \%$. Selanjutnya untuk proses pembuatan susu kedelai, diterangkan sebagai berikut:

1) Pertama biji kedelai yang telah dipersiapkan direndam dalam air selama satu malam. Air rendaman dibuang.

2) Biji kedelai dihancurkan dengan menggunakan blender dengan disertai penambahan air panas sebanyak 7 kali berat kedelai kering, selanjutnya dilakukan penyaringan dengan kain saring yang cukup halus.

Berdasarkan latar belakang diatas, penulis menggunakan bahan lokal susu kedelai dan rosella sebagai tambahan dalam pembuatan pudding bavarois. Pembuatan pudding bavarois sukedbula, akan meningkatkan manfaat susu kedelai dan bunga rosella menjadi produk yang bergizi tinggi dan bernilai jual.

\section{METODE PENELITIAN}

\section{A. Rancangan Penelitian}

Penelitian ini menggunakan metode eksperimen untuk memperoleh data dengan melakukan percobaan pembuatan pudding bavaroise sukedbula, yang dibuat dari susu kedelai dan bubuk bunga rosella. Eksperimen dilakukan di laboratorium Tata Boga Akademi Kesejahteraan Sosial Ibu Kartini Semarang, beralamat di Jalan Sultan Agung nomer 77 Semarang. Waktu yang digunakan selama 3 (tiga) bulan, yaitu dari bulan April sampai dengan bulan Juni pada tahun 2020. 
B. Rancangan Percobaan

Rancangan percobaan pada penelitian ini menggunakan Rancangan Acak Lengkap, dengan kombinasi 4 perlakuan dan 3 ulangan. Eksprimen pembuatan pudding bavarois susu kedelai bunga rosella dengan menggunakan bahan tambahan rosella bubuk, dengan perbandingan $0 \%, 10 \%, 20 \%$, dan $30 \%$ bubuk rosella yang akan digunakan. Masing-masing produk diberi kode P0 untuk pudding control, P1 untuk produk pudding bavarois dengan penggunaan rosella 10\%, kode P2 untuk pudding bavarois dengan penggunaan rosella 20\%, dan kode P3 untuk pudding bavarois dengan penggunaan rosella 30\%. Teknik pengambilan sampel yaitu Simple Random Sampling. Produk pudding yang diujikan kepada 35 panelis semi terlatih yaitu mahasiswa Program Studi Tata Boga Akademi Kesejahteraan Sosial Ibu Kartini Semarang.

C. Alat dan Bahan

Peralatan sebagai penunjang keberhasilan eksperimen dalam pembuatan pudding bavarois susu kedelai bunga rosella harus memadai, sehingga produk yang dihasilkan maksimal. Jenis peralatan yang digunaan pada pembuatan pudding bavarois susu kedelai bunga rosella, yaitu kompor, timbangan, baskom, mixer, gelas ukur, timbangan digital, spatula, dan cetakan.

Bahan yang digunakan untuk membuat pudding bavarois harus berkualitas baik, sehingga produk yang akan dihasilkan juga maksimal dari segi rasa, warna, tekstur, bentuk dan aroma. Spesifikasi bahan yang digunakan dalam pembuatan pudding bavarois susu kedelai bunga rosella yaitu tepung agar-agar, telur, gula pasir, bubuk bunga rosella, susu kedelai, dan garam.

Proses pembuatan pudding bavarois susu kedelai bunga rosella (sukedbula) yaitu pengukuran bahan sesuai formula yang ditetapkan. Perebusan cairan agar-agar, gula pasir, garam, dan susu kedelai dengan api sedang hingga mendidih sambil diaduk. Penambahan bubuk rosella bubuk, dimasak selama 3 (tiga) menit sambil diaduk hingga rata, selanjutnya diangkat dari kompor.

Langkah berikutnya dilakukan penyaringan cairan agar-agar untuk memisahkan kotoran dari sisa bahan. Proses selanjutnya mencampur cairan susu agar-agar dengan foam putih telur, lakukan pencetakan, dan pendinginan yang dilakukan pada refrigerator selama 30 menit.

D. Metode Analisis

Metode analisis data yang telah terkumpul, menggunakan analisis kualitatif dan kuantitatif yaitu untuk mengetahui tingkat kesukaan masyarakat, menggunakan analisis deskriptif penilalaian rerata, sedangkan uji laboratorium untuk analisis secara kimiawi.

\section{HASIL DAN PEMBAHASAN}

A. Penilaian Sensori

Penilaian sensori yang dilakukan terdiri dari uji organoleptic, yang dilakukan oleh panelis semi terlatih, yang selanjutnya hasil dijelaskan secara deskriptif terhadap atribud warna, rasa, aroma, tekstur (Agusman, 2013). Hasil penilaian sensorik terhadap pudding sukedbula, sebagai berikut: 
1. Warna

Pudding bavarois sukedbula yang dihasilkan dengan perlakuan P2, dengan menambahkan bubuk bunga rosella sebanyak $20 \%$ dari total bahan kering, menghasilkan warna yang paling disukai oleh panelis. Warna pudding bavaroise sukedbula yang ditambahkan bubuk bunga rosella $22 \mathrm{~g}$ mengahsilkan warna pudding merah muda cerah dan menarik.

Pudding bavarois sukedbula perlakuan P1 yang ditambahkan bubuk bunga rosella sebanyak $11 \mathrm{~g} \mathrm{(10 \% )} \mathrm{mempunyai} \mathrm{warna} \mathrm{merah} \mathrm{yang} \mathrm{terlalu} \mathrm{muda,} \mathrm{sedangkan}$ perlakuan P2 yang ditambahkan bubuk bunga rosella sebanyak $33 \mathrm{~g}$ atau $30 \%$ mempunyai warna merah muda namun agak pekat, sehingga kedua pudding dengan perlakuan P1 dan P3 kurang disukai panelis.

Berdasarkan penilaian dari segi warna diketahui rerata tingkat kesukaan panelis terhadap Pudding bavarois sukedbula berkisar dari 3.2 sampai dengan 3.8. Pudding bavaroise sukedbula dengan yang menambahkan $20 \%$ bubuk rosella dengan rerata 3.8 paling disukai, dan produk penambahan bubuk bunga rosella $30 \%$ dengan rerata 3.6 lebih disukai dibandingkan produk penambahan bubuk rosella dengan rerata 3.2.

2. Rasa

Pudding bavarois dengan perlakuan P2, yaitu yang ditambahkan bubuk bunga rosella sebanyak $20 \%$ atau $22 \mathrm{~g}$ dari total bahan kering, mempunyai rasa yang manis asam segar yang pas, sehingga lebih disukai panelis, dibandingkan yang perlakuan P1 $(10 \%)$ bubuk rosella yang rasanya hanya manis dan asamnya kurang, serta perlakuan P3 dengan penambahan $30 \%$ bubuk bunga rosella yang mempunyai rasa manis namun terlalu asam, sehingga pudding dengan perlakuan P1 dan P3 kurang disukai panelis.

Penilaian rerata terhadap Pudding bavarois sukedbula diketahui berkisar dari 2.4 sampai dengan 3.6. Perlakuan P1 (10 \%) nilai reratanya 2.4, perlakuan P2 (20 \%) reratanya 3.6, sedangkan perlakuan P3 (30\%) nilai reratanya 3.3. Maka nilai tersebut menunjukkan bahwa tingkat kesukaan panelis terhadap pudding bavarois kedbula yaitu perlakuan P2 dengan penambahan bubuk bunga rosella sebanyak $20 \%$.

3. Aroma

Penilaian Pudding bavarois sukedbula dengan perlakuan P2, yaitu yang ditambahkan bubuk bunga rosella sebanyak $20 \%$ atau $22 \mathrm{~g}$ dari total bahan kering, mempunyai aroma yang cukup segar khas bunga rosella, sehingga lebih disukai panelis, dibandingkan yang perlakuan P1 $(10 \%)$ bubuk rosella yang aromanya hambar, serta perlakuan P3 dengan penambahan $30 \%$ bubuk bunga rosella yang mempunyai terlalu tajam, sehingga pudding dengan perlakuan P1 dan P3 kurang disukai panelis.

Penilaian rerata terhadap Pudding bavarois sukedbula diketahui berkisar dari 2.6 sampai dengan 3.4. Perlakuan P1 (10 \%) nilai reratanya 2.6, perlakuan P2 (20\%) reratanya 3.4, sedangkan perlakuan P3 (30\%) nilai reratanya 2.8. Maka nilai tersebut menunjukkan bahwa tingkat kesukaan panelis terhadap Pudding bavarois sukedbula yaitu perlakuan P2 dengan penambahan bubuk bunga rosella sebanyak $20 \%$.

4. Tekstur

Pudding bavarois sukedbula dengan perlakuan P2, yaitu yang ditambahkan bubuk bunga rosella sebanyak $20 \%$ atau $22 \mathrm{~g}$ dari total bahan kering, mempunyai kepadatan busa yang pas (foamy), sehingga lebih disukai panelis, dibandingkan yang perlakuan P1 (10 \%) maupun perlakuan P3 (30 \%), namun secara umum dari ketiga perlakuan mempunyai tekstur yang hampir sama untuk kepadatan busanya. 
Penilaian rerata terhadap Pudding bavarois sukedbula diketahui berkisar dari 3.2 sampai dengan 3.6. Perlakuan P1 (10 \%) nilai reratanya 3.2, perlakuan P2 (20\%) reratanya 3.8, sedangkan perlakuan P3 (30\%) nilai reratanya 3.6. Maka nilai tersebut menunjukkan bahwa tingkat kesukaan panelis terhadap Pudding bavarois kedbula yaitu perlakuan P2 dengan penambahan bubuk bunga rosella sebanyak $20 \%$.

B. Daya Terima Masyarakat

Daya terima masyarakat dengan menggunakan penilaian tingkat kesukaan (hedonik) terhadap Pudding bavarois sukedbula, indikator penilaian melalui kualitas rasa, warna, tekstur, dan aroma, dengan memberi nilai tidak suka, kurang suka, suka, cukup suka, dan sangat suka (Rahayu, W.P., 2001). Berikut hasil uji hedonik terhadap Pudding bavarois susu kedelai bunga rosella eksperimen ketiga. Sebagai hasil akhir, indikator yang digunakan dalam pengamatan hasil terpilih pada perlakuan P2, yaitu dengan penambahan bubuk rosela $20 \%$.

C. Kandungan Gizi Pudding bavarois Susu Kedelai Bunga Rosella

Berdasarkan hasil uji organoleptic dengan uji hedonic (kesukaan) Pudding bavarois susu kedelai bunga rosella (sukedbula) terbaik terhadap rasa, warna, aroma, dan tekstur, maka perlakuan terbaik diperoleh pada perlakuan P2 dengan penambahan rosella bubuk $20 \%$. Pengamatan penunjang untuk perlakuan terbaik pada pudding bavarois susu kedelai bunga rosella, maka dilakukan uji kimiawi terhadap vitamin C, lemak dan protein, yang dilakukan di laboratorium kimia Politeknik Katolik Mangunwijaya.

Gizi yang terkandung didalam pudding bavarois sukedbula dari hasil uji kimiawi, diterangkan sebagai berikut:

1. Kadar Vitamin C

Pengujian kadar vitamin C yang dilakukan pada Pudding bavarois susu kedelai bunga rosella $2.4 \%$. Kadar vitamin C yang terkandung pada Pudding bavarois sukedbula banyak berasal dari bunga rosella, meskipun bahan lainnya juga mengandung vitamin C. Vitamin C pada serbuk bunga rosella sebanyak $14 \%$ per 100 g. Penggunaan serbuk rosella pada pudding bavaroise sukedbula yang diuji kimiawi sebanyak 20 g setara $2.8 \%$, namun setelah digunakan sebagai perasa dan pewarna pada pudding bavaroise sukedbula kadar vitamin $\mathrm{C}$ menjadi $2.4 \%$, maka mengalami sedikit penurunan yaitu $0.4 \%$. Vitamin $\mathrm{C}$ yang terdapat pada pudding bavaroise sukedbula masih cukup baik, meskipun mengalami sedikit penurunan, sehingga manfaat dari bunga rosella sebagai antioksidan masih ada. Penurunan kadar vitamin C dipengaruhi oleh proses pemanasan pada saat dicampurkan pada cairan agar-agar.

\section{Kandungan Protein}

Kandungan protein dari Pudding bavarois didapatkan dari bahan utama yang digunakan, yaitu bersumber dari susu kedelai dan putih telur. Kandungan protein pada susu kedelai yaitu $4.48 \%$ per 100 g, sedangkan pada putih telur sebanyak mengandung $4.7 \%$ per $100 \mathrm{~g}$. Total sumber protein pada bahan penyumbang protein terbanyak yaitu $500 \mathrm{~g}$ susu kedelai dan 50 g putih telur sebanyak $22.4 \%$ dan $2.3 \%$, total protein per $100 \mathrm{~g}$ bahan menjadi $5.1 \%$.

Berdasarkan hasil hasil uji kimia yang telah dilakukan pada pudding bavarois susu kedelai bunga rosella mengandung protein sebanyak 4,35\% per $100 \mathrm{~g}$ pudding. Protein yang berasal dari bahan utama dan setelah dilakukan pengolahan menjadi protein mengalami sedikit penurunan, yaitu sebanyak $0.75 \%$, sehingga pudding tersebut masih cukup bagus kandungan proteinnya dan layak dikonsumsi. Penurunan 
disebabkan karena kerusakan protein atau denaturasi. Denaturasi protein pada pudding bavaroise sukedbula tidak terlalu banyak.

Beberapa penyebab kerusakan protein diantaranya karena panas, karena zat asam, dan gula (Demodaran, S., 1997). Panas merupakan agen fisik umum yang dapat mendenaturasikan protein (Tan, T. C., 2012). Derajat keasaman dapat mendenaturasikan protein, pada pudding bavaroise sukedbula terdapat bubuk bunga rosella yang mengandung derajat keasaman. Gula yang digunakan pada Pudding bavarois sukedbula, disaat proses pemasakan meningkatkan suhu panas pada adonan, sehingga dapat mendenaturasikan protein.

3. Kandungan Lemak

Hasil uji kimiawi terhadap Pudding bavarois sukedbula menunjukkan angka $0.32 \%$. Lemak yang terkandung pada Pudding bavarois sukedbula bersumber pada $500 \mathrm{~g}$ susu kedelai dan $50 \mathrm{~g}$ putih telur, lemak yang terkandung masing-masing $9.6 \%$ dan $0.035 \%$, total lemak pada bahan sebanyak $9.635 \%$. Bila dihitung per $100 \mathrm{~g}$ bahan susu kedelai dan putih telur, maka mengandung lemak sebanyak $1.927 \%$. Selisih angka kandungan lemak bahan dan setelah diolah menjadi Pudding bavarois sukedbula mengalami penurunan sebanyak $1.6 \%$. Penurunan kadar lemak dipengaruhi oleh pemanasan, karena lemak banyak berasal dari susu kedelai, dan lemak tersebut merupakan lemak tak jenuh, bahwa lemak tak jenuh akan rusak yang disebabkan oleh proses pemanasan (Palupi NS, 2007). Proses pemanasan terhadap susu kedelai dilakukan pada saat merebus adonan cair Pudding bavarois sukedbula.

Berdasarkan hasil uji kimia diatas, dapat disimpulkan bahwa Pudding bavarois susu kedelai bunga rosella memiliki kadar lemak yang rendah, dikarenakan telur yang digunakan hanya putihnya saja, sedangkan sumber lemak yang lain yaitu susu kedelai mengandung lemak nabati, yang aman untuk kesehatan. Sehingga Pudding bavarois susu kedelai bunga rosella cocok untuk dikonsumsi sebagai dessert oleh orang yang diet rendah lemak dan kolesterol.

\section{KESIMPULAN}

Pudding bavarois sukedbula perlakuan terpilih setelah diuji yaitu pada perlakuan pemanfaatan bubuk rosella sebanyak $10 \%$ yaitu 11 gram yang dimanfaatkan pada pembuatan Pudding bavarois sukedbula. Pudding bavarois sukedbula tersebut mengandung kadar $24 \%$ vitamin C, $0.32 \%$ fat, dan $4.35 \%$ protein. Secara deskriptif penilaian sensorinya menghasilkan pudding bavaroise sukedbula berwarna merah muda cerah 3.8, berasa manis dan asam yang segar 3.6, bertekstur padat berbusa lembut (foamy) 3.6, beraroma khas bunga rosela 3.4, serta kesukaan keseluruhan disukai panelis 3.6. Saran pada penelitian selanjutnya disarankan melakukan pengujian daya simpan dan teknik penyimpanan yang tepat terhadap Pudding bavarois sukedbula, selanjutnya penyajian disarankan untuk menambahkan pelengkap berupa vla atau saus.

\section{BIBLIOGRAPHY}

Agusman. 2013. Pengujian Organoleptik. Semarang : Teknologi Pangan Universitas Muhammadiyah Semarang. 
Dapur Kirana. 2013. Minuman Favorit ala Cafe dari Susu Kedelai. Jakarta : PT Gramedia Pustaka Utama.

Demodaran, S. and Paraf, A. 1997. Food Proteins and Their Applications. Marcel Dekker Inc. New York.

Dwi, Nurmala. 2014. Seri Belajar Memasak Puding. Jakarta : Demedia Pustaka.

Faridah, Ani dkk. 2008.Patiseri Jilid 3 untuk SMK. Jakarta: Direktorat Pembinaan Sekolah Menengah Kejuruan, Direktorat Jenderal Manajemen Pendidikan Dasar dan Menengah, Departemen Pendidikan Nasional.

Fauziati., Sampepana E. 2012. Pemanfaatan Ekstrak Bunga Rosella Sebagai Bahan Pewarna Alami Pada Kacang Goyang. Laporan Penelitian. Jurnal Riset Teknologi Industri. Samarinda

Habsari, Rinto. 2003. Pudding Busa Dan Susu. Jakarta : PT Gramedia Pustaka Utama.

Handarini, K., 2014. Potensi Ekstrak Bunga Rosella (Hibiscus Sabdariffa L.) Sebagai Pewarna Dan Pengawet Alami Pada Jelly Jajanan Anak. Jurnal Teknik Industri Heuristic, 11 (2), 32-42.

Hindah Muaris. 2006. Pudding Susu Kedelai Tinggi Protein \& Rendah Kolesterol. Jakarta : PT Gramedia Pustaka Utama.

Ismayani, Yeni. 2013. Step By Step Pudding Agar-Agar \& Cake Pudding. Jakarta: PT Gramedia Pustaka Utama.

Maryani, H dan L. Kristina. 2008. Khasiat dan Manfaat Rosella. Jakarta: PT. Agromedia Pustaka.

Pusat Informasi Wanita Dalam Pembangunan. 2000. Susu Kedelai (TTG Tepatguna). Jakarta: Deputi Menegristek Bidang Pendayagunaan dan Pemasyarakatan Ilmu pengetahuan dan teknologi.

Rahayu, W.P. 2001. Penuntun Praktikum Penilaian Organoleptik. Bogor: Fakultas Teknologi Pangan. IPB.

Sarwani Hasibuan, Mardinah, Saptuti. 2009. Aplikasi Pewarna Alami Antosianin dari Kelopak Rosella Pada Produk Yoghurt dalam Rangka Penganekaragaman Produk Pangan Fungsional. Bogor: Fakultas Agribisnis dan Teknologi Pangan Universitas Djuanda Bogor.

Suryaatmaja, Poppy Dkk. 2008. Rosella Aneka Olahan, Khasiat, \& Ramuan. Jakarta: Penebar Swadaya.

Suwandi, T. 2012. Pemberian Ekstrak Kelopak Bunga Rosella Menurunkan Malondialdehid Pada Tikus Yang Diberi Minyak Jelantah. Tesis. Program Studi Ilmu Biometrik Universitas Ubayana. Denpasar. 